Article

\title{
Pharmacy Practice and Education in Slovenia
}

\author{
Borut Božič ${ }^{1}$, Aleš Obreza ${ }^{1}$ and Jeffrey Atkinson ${ }^{2, *}$ \\ 1 Faculty of Pharmacy, University of Ljubljana, Aškerčeva 7, SI-1000 Ljubljana, Slovenia; \\ Borut.bozic@ffa.uni-lj.si (B.B.); ales.obreza@ffa.uni-lj.si (A.O.) \\ 2 Pharmacolor Consultants Nancy, 12 rue de Versigny, 54600 Villers, France \\ * Correspondence: jeffrey.atkinson@univ-lorraine.fr
}

Received: 25 September 2018; Accepted: 17 December 2018; Published: 24 December 2018

check for updates

\begin{abstract}
The PHARMINE ("Pharmacy Education in Europe") project studied pharmacy practice and education in the European Union (EU) member states. The work was carried out using an electronic survey sent to chosen pharmacy representatives. The surveys of the individual member states are now being published as reference documents. This paper presents the results of the PHARMINE survey on pharmacy practice and education in Slovenia. In the light of this, we examine the harmonisation of practice and education in Slovenia with EU norms.
\end{abstract}

Keywords: pharmacy; education; practice; Slovenia; European Union

\section{Introduction}

The PHARMINE ("Pharmacy Education in Europe") consortium surveyed pharmacy practice and education in the European Union (EU) member states, including Slovenia, between 2008 and 2011, with an update in August 2017. The methodology used and the main results obtained have been published [1]. PHARMINE gathered information on community practice, on specialised hospital and industrial practice, as well as on the mandatory education and training. PHARMINE also dealt with other personnel working in pharmacies such as pharmacists' assistants.

PHARMINE went on to study the administrative context of pharmacy practice and education in the EU context. Like any individual country, the EU has an executive body, a legislative body and a judiciary-all features normally associated with government. Albeit, these bodies operate differently from those of an individual country. The overall governing body of the EU—-the European Council—is composed of the representatives of the national governments of the member states. The EU does not govern directly the member states. It does pass legislation, but it is dependent on member states to implement it. Two aspects of EU legislation are important for pharmacy practice and education. The first concerns the free movement of people and the right of EU professionals to exercise their profession without hindrance in any member state. The second concerns the right of citizens in all member states to receive healthcare of a similar, high standard. Thus, in contrast to other parts of the world, EU pharmacy practice and education fall under two jurisdictions: EU and national. EU legisaltion is confederal in structure. Freedom of movement and of exercise of profession is the cornerstone. There is a system of automatic recognition of professional qualifications for sectoral professions such as pharmacists, as well as doctors, nurses, midwives, dentists, veterinary surgeons and architects. To work in another EU member state, professionals apply to the national authority, providing proof of the qualifications obtained in their home state. Procedures are regulated by directives issued by the European Commission of the EU. Directives are ordinances laying down the broad imperatives on practice and education [2]. A directive requires member states to achieve a particular result (e.g., harmonisation of pharmacy practice and education) but does not lay down inflexible means to obtain that result. Directives leave leeway as to the exact rules adopted. The result of this process is that member states have systems that are more or less harmonised with EU norms. 
In parallel to the above pan-national system, member states may introduce national legislation relating for example to specialised practice, and to ownership and management of pharmacies.

Pharmacy education and training in Europe is also influenced by the Bologna agreement on the harmonization of student and staff exchange and European degree courses [3]. The Bologna agreement was signed by the education ministers of the countries of the European Higher Education Area (48 members including the $28 \mathrm{EU}$ member states). It proposes recommendations that are not legally binding. These include a harmonised structure for all university degrees (including pharmacy) with a bachelor's (3 years) followed by a master's (2 years) degree. Here, the Bologna agreement is in opposition to the EU directive. The latter requires a five-year, "tunnel" degree structure for pharmacy, i.e., a degree course that offers no possibility for intermediate entry or exit after accomplishment of a three-year bachelor's period.

The idea behind the Bologna recommendations is to improve student mobility with the development of tools to promote student exchange programmes like the European Credit Transfer and Accumulation System (ECTS). This provides credits to students for defined learning outcomes. ECTS are coupled with a Diploma Supplement that describes the nature, level, context, content and status of the studies that were successfully completed by a student. This system allows students to validate studies carried out at their host university by their home university.

This paper looks at how the EU directive and the Bologna recommendations apply in a recent member of the EU (membership in 2007), Slovenia.

Slovenia is by its geographic position and development a part of Central Europe. It is in the group of high income countries. In order to place practice within the general health situation in Slovenia compared to Europe, it can be noted that life expectancy at birth (Table 1) in Slovenia is higher than the European average of 77 years. Healthy life expectancy (European average 68 years) is also higher. Expenditure on health is slightly lower than the European average ( $9.4 \%$ of GDP). Slovenia shows a tendency towards an ageing population with similar problems of health care and social care system as elsewhere in EU. Slovenia has a well distributed primary health care system with regional hospitals and two university medical centres for tertiary health care service.

Table 1. Health statistics for Slovenia $[4,5]$.

\begin{tabular}{cc}
\hline Total Population & $\mathbf{2 , 0 6 5 , 8 7 9}$ \\
\hline Life expectancy at birth (years) & 81 \\
Healthy life expectancy at birth (years) & 71 \\
Total health expenditure as \% of GDP & 8.7 \\
\hline
\end{tabular}

\section{Design}

Information was obtained from academics and practicing pharmacists and from internet sources on:

- pharmacy;

i. practice: community, hospital and industrial;

ii. legislation;

iii. education and training;

- harmonisation with the EU sectoral directive on pharmacy [2] and with the Bologna recommendations [6].

Electronic survey methodology was used; data was collected in 2010 and revised in August 2017. We attempted at all times to collect objective (often numerical) data.

The information is presented in the form of tables in order to facilitate legibility. This type of presentation was developed in association with the journal's editorial board and has been described in detail in a previous publication [7]. This format will ease the comparison of different EU countries by 
students and staff envisaging exchange programmes, and by researchers in pharmacy education and practice. It should be noted that this article is not intended to be a classical research manuscript but more a descriptive, qualitative research article.

\section{Evaluation and Assessment}

\subsection{Organisation of the Activities of Pharmacists, Professional Bodies}

Table 2 provides details of the numbers and activities of community pharmacists and pharmacies in Slovenia. Items are expounded in the "comments" column.

Table 2. Numbers and activities of Slovenian community pharmacists and pharmacies [8].

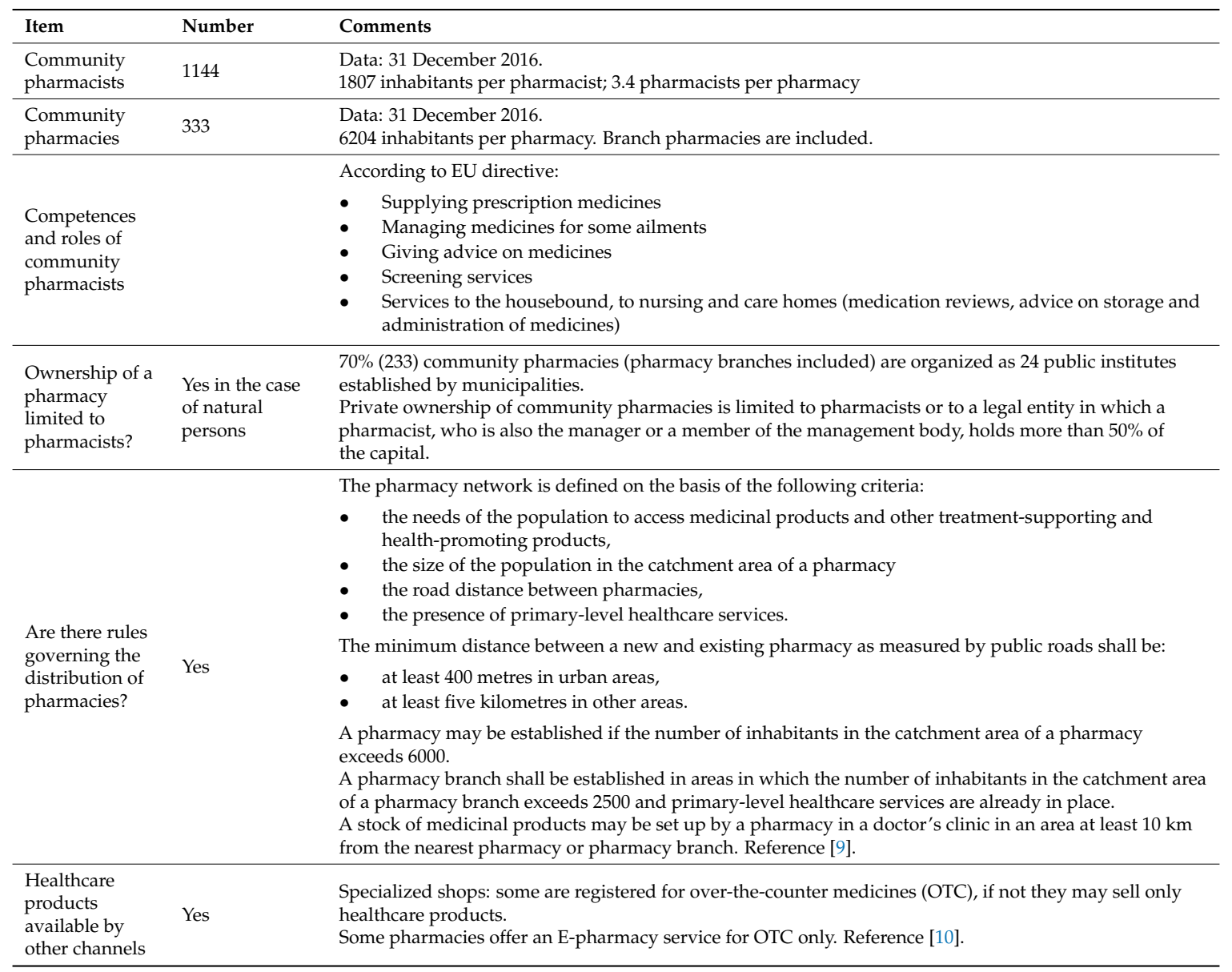

It should be noted that in law a "natural person" is an individual human being (as opposed to a legal person either private (business entity or non-governmental organization) or public (government) organization).

The number of pharmacists per population is much lower than the EU norm. Using the data in Ref. [1] and Table 2, it can be calculated that, compared to the EU linear regression estimation (for definition and calculation, see [1]), the ratio of the number of community pharmacists in Slovenia/population compared to the linear regression estimation $=0.24$. The same comparison for community pharmacies produces a ratio of 0.18 , again much lower than the EU norm. The number of pharmacists/pharmacy (3.4) is higher than the EU average of $2.1 \pm 0.7$ [1].

The activities and occupations of pharmacists in Slovenia are similar to those of community pharmacists in other EU member states [1].

Table 3 provides details of the numbers and activities of persons other than pharmacists working in pharmacies in Slovenia. 
Table 3. Numbers and activities of other personnel working in pharmacies in Slovenia [11].

\begin{tabular}{lll}
\hline Item & Number & Comments \\
\hline Titles and number & 523 & $\begin{array}{l}\text { Pharmacists' assistants (pharmacy technicians). Data from } \\
\text { 31 December 2016. } \\
\text { There are 1.57 pharmacists' assistants/pharmacy }\end{array}$ \\
\hline $\begin{array}{l}\text { Organisation providing } \\
\text { training }\end{array}$ & $\begin{array}{l}\text { Secondary school for pharmacy, cosmetics and healthcare in Ljubljana } \\
\text { and pharmacy programs at secondary schools in Ruše and Novo Mesto }\end{array}$ \\
\hline Duration of studies & $\begin{array}{l}\text { 4 years secondary } \\
\text { education }+6 \text { months' } \\
\text { probation }\end{array}$ & $\begin{array}{l}\text { The program for pharmacy technicians comprises } 4 \text { years of secondary } \\
\text { education (at age 15-19 years), a final exam at the end of the secondary } \\
\text { school and } 6 \text { months' probation in a pharmacy }\end{array}$ \\
\hline Competences and roles & $\begin{array}{l}\text { Supply of non-prescription medicines and non-medicinal } \\
\text { healthcare products } \\
\text { Storage and managing of medicines, including ex } \\
\text { tempore preparations }\end{array}$ \\
\hline
\end{tabular}

Turning to specialisation in pharmacy practice, Table 4 provides the numbers and activities of hospital pharmacists in Slovenia.

Table 4. Numbers and activities of hospital pharmacies and pharmacists.

\begin{tabular}{|c|c|c|}
\hline Item & Number & Comments \\
\hline Hospital pharmacists & 124 & $\begin{array}{l}\text { They are organized as a section of the Slovenian chamber of pharmacy [8] } \\
\text { Data from } 31 \text { December } 2016 \text {. }\end{array}$ \\
\hline Hospital pharmacies & 27 & $\begin{array}{l}\text { Data from } 31 \text { December } 2016 . \\
4.6 \text { pharmacists per hospital pharmacy. }\end{array}$ \\
\hline \multirow[t]{2}{*}{ Competences and roles } & & $\begin{array}{l}\text { In line with the system for the recognition of professional qualifications, } \\
\text { EU directive } 2005 / 36 / \mathrm{EC}[12] \text {. } \\
\text { - } \quad \text { In- or out-patient clinics } \\
\text { - } \quad \text { Consultant in specialised clinical areas such as paediatrics or intensive care } \\
\text { - } \quad \text { Part of multidisciplinary patient-care team } \\
\text { - } \quad \text { Purchasing of drugs and medical material } \\
\text { - } \quad \text { Monitoring of drug use } \\
\text { - } \quad \text { Unit-dose drug distribution } \\
\text { - } \quad \text { Production of patient-specific medicines (cytotoxic } \\
\text { preparations, radiopharmaceuticals) }\end{array}$ \\
\hline & & Recognized competences differ from hospital to hospital. \\
\hline
\end{tabular}

The number of pharmacists working in hospitals is again lower than the EU average. The ratio of the actual number compared to the linear regression estimation is 0.28 , (for definition and calculation see Reference [1]). The ratio of hospital pharmacists is also lower (0.38).

The duties of hospital pharmacists are similar to those elsewhere in the EU. As active members of European Association of Hospital Pharmacists (EAHP), they quickly implement the novelties into everyday practise $[1,12]$.

Table 5 provides details of the pharmaceutical industry, industrial pharmacists, in Slovenia.

According to the 2017 data of the European Federation of Pharmaceutical Industries and Associations (EFPIA, [13]), $183 \mathrm{M} €$ are spent on R \& D in Slovenia. Production represents $1354 \mathrm{M} €$ and there is a positive trade balance (net export) at $1354 \mathrm{M} €$. Slovenia ranks 9 th in the EU for its positive trade balance for pharmaceuticals (it should be noted that $15 / 28$ countries in the EU have a negative trade balance) [13].

Industrial pharmacists in Slovenia fulfil similar tasks to those elsewhere in the EU [1]. A comparison of numbers with other countries is not possible given the different job descriptions and education and training of employees in the European pharmaceutical industry.

Table 6 provides details of pharmacists working in other sectors, in Slovenia. 
Table 5. Pharmaceutical industry, and industrial pharmacists.

\begin{tabular}{|c|c|c|}
\hline Item & Number & Comments \\
\hline \multicolumn{3}{|c|}{ Pharmaceutical industries } \\
\hline $\begin{array}{l}\text { Companies with } \\
\text { production, R \& D } \\
\text { and distribution }\end{array}$ & 2 & $\begin{array}{l}\text { Two companies have R \& D, production and distribution: } \\
\text { - } \quad \text { Krka: http://www.krka.biz } \\
\text { - } \quad \text { LEK/Sandoz: http:/ / www.lek.si/en/ } \\
\text { Additionally there are } 9 \text { public and } 6 \text { private companies supplying tissues and cells and medical } \\
\text { devices: www.jazmp.si. Examples: } \\
\text { - Celica biomedical: http:// celicabiomedical.com/ } \\
\text { - } \quad \text { Educel: http://www.educell.si/en/. } \\
\text { - } \quad \text { Blood transfusion centre: http://www.ztm.si/en/ }\end{array}$ \\
\hline $\begin{array}{l}\text { Companies with } \\
\text { production only }\end{array}$ & 10 & $\begin{array}{l}\text { Galenical laboratories } \\
\text { Example: } \\
\text { - } \quad \text { Galex: www.galex.si }\end{array}$ \\
\hline $\begin{array}{l}\text { Companies } \\
\text { producing generic } \\
\text { drugs only }\end{array}$ & 3 & $\begin{array}{l}\text { Krka: www.krka.biz/en } \\
\text { Galex: www.galex.si } \\
\text { Marifarm: http://www.marifarm.si/ }\end{array}$ \\
\hline \multicolumn{3}{|l|}{ Industrial pharmacists } \\
\hline $\begin{array}{l}\text { Pharmacists working } \\
\text { in industry }\end{array}$ & 1100 & $\begin{array}{l}660 \text { pharmacists work in two main factories (Krka d.d. and LEK/Sandoz). Approximately } 450 \\
\text { (data 2017) work in other pharmaceutical firms, mainly in pharmaco-informatics, trading and sales. } \\
\text { A total of } 8961 \text { persons worked in the Slovenian pharmaceutical industry in } 2017 \text { [13]. }\end{array}$ \\
\hline
\end{tabular}

Table 6. Pharmacists working in other sectors.

\begin{tabular}{|c|c|c|}
\hline Item & & Comments \\
\hline $\begin{array}{l}\text { Pharmacists working in } \\
\text { other sectors }\end{array}$ & 270 & $\begin{array}{l}\text { - } 50 \% \text { in education } \\
\text { - } \quad 20 \% \text { in laboratory medicine (clinical laboratories) } \\
\text { - } 20 \% \text { in administration and legislation } \\
\text { - } 10 \% \text { in other sectors }\end{array}$ \\
\hline Sectors & & $\begin{array}{ll}\text { - } & \text { Education (HEIs and secondary schools) } \\
\text { - } & \text { Laboratory medicine (medical/clinical laboratories) } \\
\text { - } & \text { Administration and legislation including regulators: Ministry of health; Health } \\
\text { inspectorate; Agency for pharmaceutical products and medical devices; National } \\
\text { institute of public healthNational Laboratory of Health, Environment and Food }\end{array}$ \\
\hline Competences & & $\begin{array}{l}\text { Depends on sector and position. Examples: } \\
\text { - } \quad \text { Teaching and researching } \\
\text { - } \quad \text { Clinical evaluation of methods for analyses of biological (human) samples } \\
\text { - } \quad \text { Interpretation of laboratory results } \\
\text { - } \quad \text { Chemical, biological, physical analyses of medicines and medical devices } \\
\text { - } \quad \text { Legislation about drug evaluation and registration } \\
\text { - } \quad \text { Management }\end{array}$ \\
\hline
\end{tabular}


Table 7 provides information on professional organizations for pharmacists in Slovenia and their roles in designing conditions for pharmaceutical work. There are two types of organizations: chambers and professional associations. Both are involved in the development of the pharmaceutical profession but from different positions. Membership for both is elective, but chambers have specific authorizations by law or by Government.

Core organizations for pharmacists in Slovenia are Slovene chamber of pharmacies and Slovenian pharmaceutical society. For professionals, working in the field of medical laboratories (laboratory medicine), including pharmacists are core organizations Chamber for laboratory medicine and Slovenian association for clinical chemistry and laboratory medicine. Main activities are shown in Table 7.

Table 7. Professional associations for pharmacists in Slovenia.

\begin{tabular}{|c|c|c|}
\hline Item & & Comments \\
\hline Registration of pharmacists & Yes & $\begin{array}{l}\text { According to the Law on Pharmacies (ZLD-1) [9] the Slovene Chamber of } \\
\text { Pharmacies shall perform the following tasks (amongst others): } \\
\text { - } \quad \text { keep the register of pharmaceutical practitioners employed with pharmacy } \\
\text { service providers, } \\
\text { grant, renew and revoke licences to pharmacists, } \\
\text { keep records of compliance with the conditions for granting and } \\
\text { renewing licences. } \\
\text { According to the Rules on the register of providers of Laboratory Medicine } \\
\text { (Official Gazette of RS, Nos. } 113 / 06 \text { and 15/17), the Slovenian Chamber of } \\
\text { Laboratory Medicine keeps a national register of specialists in clinical } \\
\text { chemistry/laboratory medicine and professionals with a master degree } \\
\text { (including pharmacists) working in laboratory medicine). }\end{array}$ \\
\hline $\begin{array}{l}\text { Creation of pharmacies } \\
\text { and control of territorial } \\
\text { distribution }\end{array}$ & Yes & $\begin{array}{l}\text { A new pharmacy or pharmacy branch is established after obtaining the (positive) } \\
\text { opinion of the Slovene Chamber of Pharmacies [8] and the consent of the } \\
\text { Ministry of Health }\end{array}$ \\
\hline $\begin{array}{l}\text { Ethical and other aspects of } \\
\text { professional conduct }\end{array}$ & Yes & $\begin{array}{l}\text { The codex of pharmaceutical ethics of the Slovenian Pharmaceutical Society is for } \\
\text { members of the society only. } \\
\text { The deontology codex in pharmacy from the Slovene chamber of pharmacies is } \\
\text { for all pharmacists, working in pharmacy praxis. } \\
\text { The deontology codex in laboratory medicine from the Slovenian Chamber for } \\
\text { Laboratory Medicine is for all who work in diagnostic laboratories, including } \\
\text { pharmacists. }\end{array}$ \\
\hline $\begin{array}{l}\text { Involvement in HEI } \\
\text { courses for pharmacists }\end{array}$ & & $\begin{array}{l}\text { The Chamber together with the Faculty of Pharmacy organises and supervises } \\
\text { the practical training of pharmacy students. The Chamber of Pharmacies obliges } \\
\text { pharmacists to undergo regular continuous professional development and also } \\
\text { organizes two-day educations for pharmacists every year. }\end{array}$ \\
\hline
\end{tabular}

\subsection{Pharmacy Faculties, Students, and Courses}

Table 8 provides details of pharmacy higher-education institutions (HEIs), staff and students in Slovenia.

Table 8. Pharmacy higher education institutions (HEIs), staff, and students in Slovenia.

\begin{tabular}{lll}
\hline Item & Comments \\
\hline Number of HEIs & 1 & University of Ljubljana (UL), Faculty of Pharmacy [14] \\
\hline & & $\begin{array}{l}\text { Not in pharmacy where there is a fully integrated 5-year program. } \\
\text { The faculty also teaches: }\end{array}$ \\
$\begin{array}{l}\text { Bachelor + master degrees } \\
\text { B + M }\end{array}$ & No & B + M degrees in laboratory medicine \\
& $-\quad \begin{array}{l}\text { B in Cosmetic sciences } \\
\text { for pharmacy practice as laid out in the EU directive [2]. }\end{array}$ \\
$\begin{array}{l}\text { Number of teaching } \\
\text { staff (nationals) }\end{array}$ & 82 & $\begin{array}{l}\text { Full time employment (FTE) at the faculty } \\
\text { An additional workload (about 20 FTE) is provided by circa } 100 \text { teachers and } \\
\text { assistants from other faculties (medicine, chemistry, mathematics and physics). }\end{array}$ \\
\hline
\end{tabular}


Table 8. Cont.

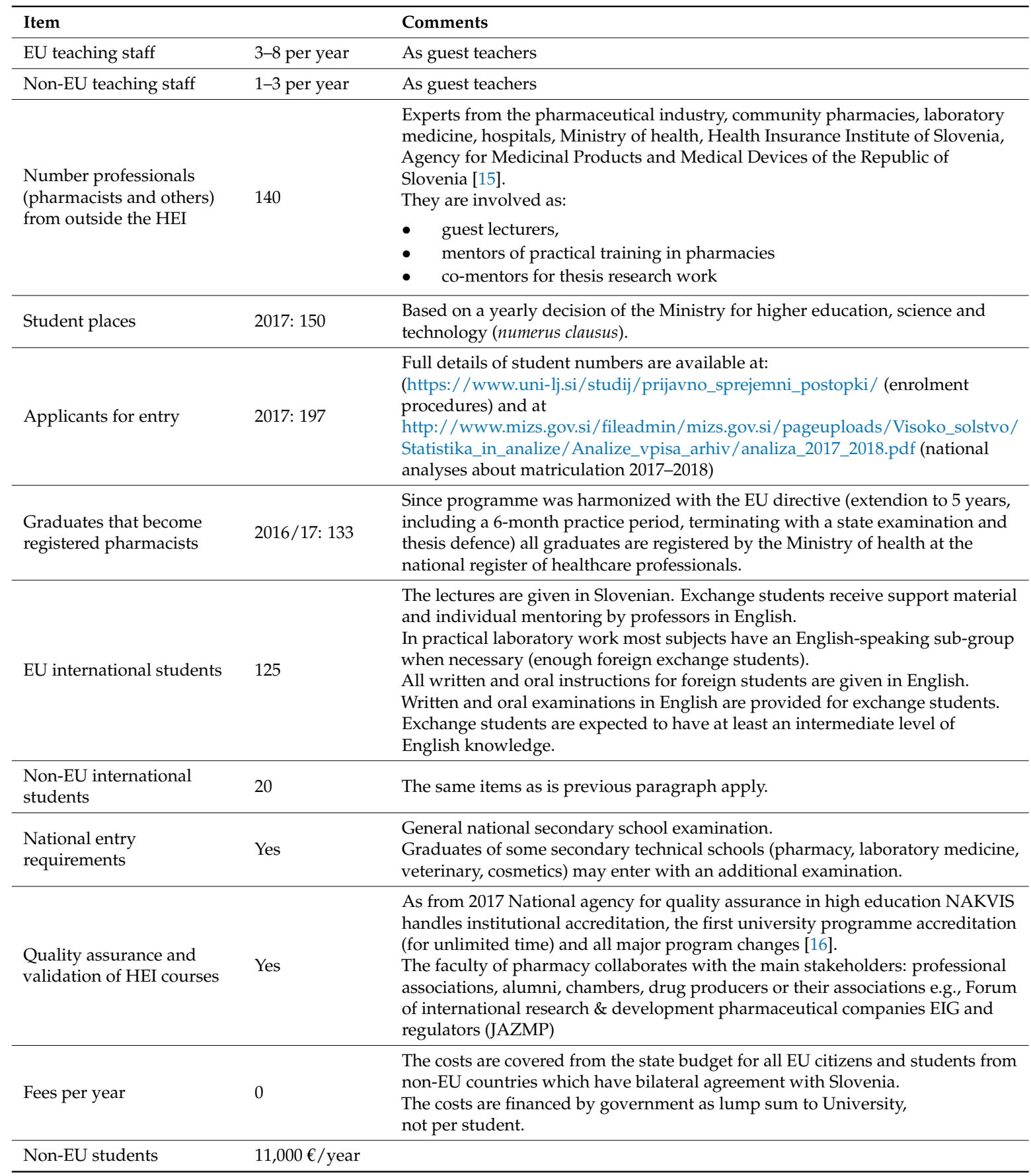

A comparison to the EU average for staff shows that Slovenia has a ratio of 1.24, for students 1.57 and for pharmacy HEIs 1.35 [1].

There are at least two levels of pharmacists' professional orientation or specialization. One is pregraduate "in-program" by elective courses in the 3rd and 4th year of the programme, and by selection of the research topic of the master's thesis. Table 9 provides details of past and present changes in pharmacy education and training in Slovenia.

Another is post master specialization as training at the work place combined with theoretical part, and second master degree. Table 10 below contains details of specialisations of pharmacists as postmaster training. 
Table 9. Past and present changes in education and training in Slovenian pharmacy education and training.

\begin{tabular}{|c|c|c|}
\hline Item & & Comments \\
\hline $\begin{array}{l}\text { Major changes } \\
\text { since } 1999\end{array}$ & Yes & $\begin{array}{l}\text { - Harmonisation with EU directive (six-month training in pharmacy), when } \\
\text { Slovenia entered the EU in } 2004 \text { [14]. } \\
\text { - Implementation of Bologna reform in } 2007 \text { to } 2011 \text { and later fine tuning of } \\
\text { courses (including modifications in ECTS) with modification in examinations } \\
\text { - } \quad \text { Orientation to competence based education and examination } \\
\text { - Introduction of radiopharmacy as national specialization } \\
\text { Reorganization of two specializations (community and clinical pharmacy) } \\
\text { into one. }\end{array}$ \\
\hline
\end{tabular}

Table 10. Specialisation electives in pharmacy HEIs in Slovenia.

\begin{tabular}{|c|c|c|}
\hline Item & & Comments \\
\hline Specialized courses? & Yes & $\begin{array}{l}\text { Different types of specialized courses are available: } \\
\text { - } \quad \text { Elective courses during integrated ( } 5 \text { years) master program of Pharmacy } \\
\text { - } \quad \text { Master program of Industrial pharmacy } \\
\text { Theoretical part of postgraduate specialisation programmes is performed } \\
\text { by HEI in cooperation with the Slovene Chamber of Pharmacies and the } \\
\text { Slovenian Chamber for Laboratory Medicine. Such courses (but not the } \\
\text { whole specialization) are open to graduates with a master degree in science } \\
\text { as well as to pharmacists. } \\
\text { - Doctoral programme of Biomedicine with } 11 \text { fields [17] }\end{array}$ \\
\hline Which years? & Different & $\begin{array}{l}\text { Depends on programme: } \\
\text { - } \quad \text { Electives in 3rd and 4th year and topic of master thesis in the 5th year } \\
\text { of Pharmacy } \\
\text { - } \quad \text { 1st and 2nd year and topic of master thesis of Industrial pharmacy } \\
\text { - } 1 \text { st year of postgraduate specialization trainings. } \\
\text { - } 11 \text { fields including pharmacy, toxicology, laboratory medicine, electives in } \\
\text { the 2nd year of doctoral study Biomedicine, the topic of doctoral thesis }\end{array}$ \\
\hline $\begin{array}{l}\text { Which } \\
\text { specialisations? }\end{array}$ & & $\begin{array}{l}\text { Postgraduate } 3 \text { or } 4 \text { years specialization training (for details, see ref [18]): } \\
\text { - } \quad \text { Community and clinical pharmacy (3 years) } \\
\text { - } \quad \text { Clinical biochemistry (4 years) } \\
\text { - } \quad \text { Pharmacognosy ( } 3 \text { years) } \\
\text { - } \quad \text { Radiopharmacy (discontinuous modular type) } \\
\text { - } \quad \text { Analysis of Pharmaceutical Products (3 years) } \\
\text { - } \quad \text { Pharmaceutical Engineering (3 years) }\end{array}$ \\
\hline
\end{tabular}

Three-year specialisation programmes are completed by a terminal examination and presentation of a written work in the form of research/professional thesis. Four-year specialisation in clinical chemistry is equivalent to the EuSpLM [19] programme with a terminal examination, organized by the Chamber of Laboratory Medicine [20]. Postgraduate European Radiopharmaceutical Chemistry/Radiopharmacy Course [18], organized by the Faculty of pharmacy, University of Ljubljana [14] is recognized by the European Association of Nuclear Medicine (EANM) Radiopharmacy Committee as theoretical module 1 of the post-graduate specialization certificate program.

\subsection{Teaching and Learning Methods}

Learning methods applied in the program are expressed as contact hours as follows: lectures $(48 \%)$, tutorials $(12 \%)$, practical work (33\%) and project work (7) (for definitions of the different methods, see [1]). Contact hours with teacher/assistant/mentor/supervisor represent approximately $40 \%$ of total study hours and traineeship $10 \%$, which corresponds to half a year of practical work. Traineeship can be in a community or hospital pharmacy, and, for a limited number of students, a special traineeship is arranged, combining community and hospital pharmacy (there is not sufficient 
capacity in Slovenian hospitals for 150 students at the same time). For industry, traineeship lasts 12 months after graduation; it is not regulated by the Ministry of Health and is not part of the study.

\subsection{Subject Areas}

Table 11 provides details of student units by subject area (for definitions of the subject areas, see [1]).

Table 11. Student units by subject area in ECTS [21].

\begin{tabular}{ccccccccccc}
\hline Year & $\mathbf{1}$ & $\mathbf{2}$ & $\mathbf{3}$ & & $\mathbf{4}$ & \multicolumn{5}{c}{ Total } \\
\hline Subject area & & & Mi & Mx & Mi & Mx & Mi & Mx & Mi & Mx \\
\hline CHEMSCI & 22 & 16 & 24 & 29 & 13 & 26 & 0 & 15 & 75 & 110 \\
\hline PHYS-MATH & 15 & 6 & 0 & 0 & 0 & 0 & 0 & 15 & 21 & 36 \\
\hline BIOLSCI & 7 & 7 & 13 & 18 & 6 & 16 & 0 & 15 & 33 & 63 \\
\hline PHARM-TECH & 0 & 25 & 8 & 13 & 5 & 20 & 0 & 15 & 36 & 73 \\
\hline MEDISCI & 8 & 6 & 6 & 11 & 21 & 36 & 0 & 15 & 41 & 76 \\
\hline LAWSOC & 3 & 0 & 4 & 9 & 0 & 15 & 15 & 30 & 22 & 57 \\
\hline GENERIC & 5 & 0 & 0 & 1.5 & 0 & 2.5 & 25 & 25 & 30 & 34 \\
\hline
\end{tabular}

CHEMSOC: chemical sciences; PHYSMATH: physical and mathematical sciences; BIOLSCI: biological sciences; PHARMTECH: pharmaceutical technology; MEDISCI: medicinal sciences; LAWSOC: law and social sciences; GENERIC: generic competences. Mi: minimu. Mx: maximum.

Taking the MEDISCI/CHEMSCI ratio as an indicator of the nature of the content of the M. Pharm. degree courses [22], it can be seen that the course is balanced. Other countries in the EU such as Spain also have a "balanced" course. Others have more "medical" courses such as Ireland and the Netherlands with indices of 2.6 and 1.6, respectively [22].

The course in Slovenia allows for a substantial amount of flexibility in the choice of optional and elective courses. This is shown by the variability in the ranges of minimum-maximum hours, expressed in ECTS. This variability allows the choice of a more "clinical pharmacy" course or a more "industrial pharmacy" course. This represents a certain degree of pregraduate specialisation although the nomenclature of a single "degree in pharmacy" is maintained. The variability of the subject content is also influenced by the choice of the research work for the master thesis that is defended in the 5th year but which starts already in the 1st year.

An exact figure for generic competences is difficult to calculate as these are incorporated into many subject areas such as:

- Practical skills in practical work in laboratories,

- Language as part of pharmaceutical chemistry and other subjects where the relevant literature is in English,

- Communication as a part of social pharmacy as well as a part of the many subjects where student oral presentations are obligatory,

- First aid and communication as parts of traineeship,

- Specific field legislation is part of several courses dealing with particular regulative acts.

\subsection{Impact of the Bologna Principles [3]}

Slovenia like other EU countries has adopted the majority of the elements of the Bologna system such as the use of ECTS, double cycle (with exception for the programme of pharmacy or programmes for other regulated professions, which are integrated five-year programmes), and the Diploma Supplement. Accredited courses of life-long learning (LLL) have a similar structure ( $30 \mathrm{hrs}$ of student workload for 1 ECTS, 11-15 hrs of which are contact, others are individual work). All programmes 
are accredited by NAKVIS, which is a member of European Quality Assurance Register for Higher Education (EQAR). University of Ljubljana (UL) as a whole has external quality assessment by NAKVIS. The Faculty of pharmacy is a member of European association of faculties of pharmacy (EAFP) from the very beginning in 1992 and in 2015 underwent foreign external institutional evaluation by German accreditation/evaluation agency ASSIN https:/ / www.asiin.de/en/), a member of the EQAR at the European Association for Quality Assurance in Higher Education (ENQA).

Student mobility is strongly supported by HEI through bilateral agreements with 53 faculties of pharmacy: 60-100 students of pharmacy are regularly involved in Erasmus and other exchange programmes every year, approximately the same number of foreign pharmacy students are hosted every year. The main obstacle for foreign students to study in Slovenia is language. All contact hours are given in Slovenian language with exception of some elective courses, which are given in English, and defined each year by the HEI. On other courses, ERASMUS and other exchange students receive English study literature and individual consultations and mentoring in English by professors. Practical laboratory work is orgamized with English-speaking subgroups when necessary (enough foreign or exchange students). For foreign students, all written and oral instructions are given in English and written and oral examinations are provided in English as well. Stuff exchanges are enabled through Erasmus plus and the Central European Exchange Program for University Studies (CEEPUS) [23].

European dimension of pharmacy study in Slovenia is further represented by:

- Common diploma in Postgraduate European Radiopharmacy Course. The postgraduate education for the title "Radiopharmaceutical Chemist/Radiopharmacist" consists of three modules in Ljubljana (Slovenia), Zurich (Switzerland) and Leipzig (Germany). The course contents follow the guidelines of the European Association of Nuclear Medicine [24].

- Summer school in Immunology in collaboration with the Institute of Pharmacology, University of Bern, Switzerland.

- The non-clinical, pharmaceutical and early clinical development of Cooperative European Medicines Development Course (CEMDC) is an integral part of the Innovative medicines initiative (IMI) Pharmaceutical Medicine Training Programme [25].

\subsection{Impact of European Union (EU) Directive 2013/55/EC [2]}

Slovenia conforms to the EU directive with a five-year integrated study of pharmacy including a half year of practice in public or hospital pharmacies (traineeship). Compared with the earlier traineeship of 12 months (after graduation), in which it was possible to include community/hospital pharmacies, laboratory medicine and industry, six months is, in the opinion of some stakeholders, too short a period for all these aspects. In addition, only pharmacies are covered by the EU directive, not industry and laboratory medicine.

The balance between theoretical and practical training is very important as:

- Regarding traineeship, some common skills can be taught at the HEI and not separately in each pharmacy.

- A university course besides providing competences for working as a pharmacist should also provide a wider education in terms of academic literacy, problem solving, etc.

\section{Discussion and Conclusions}

The pharmacy programme including a six-month training as a part of study programme is completely harmonized with EU directives for all students; although, in Slovenia, only half of graduates are employed in public and hospital pharmacies. This affects the study programme, which enables students to developed competences, in line with an EU Directive, for work also in other areas such as the pharmaceutical industry or laboratory medicine.

It cannot be neglected that, in Slovenia, the overall number of pharmacists per population is much lower than the EU norm, the number of community pharmacists/population is lower 
than in EU and also the number of community pharmacies/population is much lower than the EU norm. Only the number of pharmacists/pharmacy (3.4) is higher than the EU average of $2.1 \pm 0.7$. Slovenian pharmacy practice also has a substantial element of public ownership. Namely, municipalities are responsible for primary health care of population including the medicine supply through pharmacies. There are 24 public institutes established by one or more municipalities, which manage 233 pharmacies (including 46 pharmacy branches). Additionally, two (public) hospital pharmacies serve as a community pharmacy as well. There are 98 private pharmacies (including 11 private pharmacy branches), all with concession. The consequence of this situation compared to that in the parts of the EU where individual ownership is the rule is that pharmacies are open also in areas where profitability is not the case (responsibility of public municipalities for balanced development in public services, demographically threatened areas). Compared to ownership by pharmacy chains, the consequence is that the spectrum of medicines of different producers is wider, independent of ownership. On the other hand, private pharmacies with concession have difficulties competing with public institutes regarding the spectrum of available medicines.

The master curriculum is subject to regular adaptation and modification with special attention on development of students' competences. Since with a 5-year study programme students can only develop basic competences for a novice, not for experienced professionals, continuous professional development is more and more important. The HEI together with professional associations and chambers organize yearly continuous professional development (CPD) courses, which are evaluated by the Slovene Chamber of Pharmacies and are essential for prolongation of professional licensing. More formal professional development is enabled through postgraduate specializations, which were optimized recently to fulfil the expectations of stakeholders and to be in line with modern guidelines in community, hospital and clinical pharmacy as well as in the prosperous pharmaceutical industry.

Author Contributions: B.B. provided the data and commented on the first and subsequent versions of the manuscript. A.O. analysed the study program and commented on later versions of the manuscript. J.A. formatted the data, wrote the manuscript and coordinated the revisions.

Funding: This research received no external funding.

Acknowledgments: The authors thank the following people who contributed to this article: Tanja Kadunc, Head of Student Affairs Office, University of Ljubljana, Faculty of Pharmacy, Aškerčeva 7, SI-1000 Ljubljana, Slovenia. tanja.kadunc@ffa.uni-lj-si and www.ffa.uni-lj.si. Matjaž Tuš, Slovenian Chamber of Pharmacy, Vojkova 48, SI-1000 Ljubljana. tajnistvo@lek-zbor.si and www.lzs.si.

Conflicts of Interest: The authors declare no conflict of interest.

\section{References}

1. Atkinson, J.; Rombaut, B. The 2011 PHARMINE report on pharmacy and pharmacy education in the European Union. Pharm. Pract. 2011, 9, 169-187. [CrossRef]

2. The European Commission Directive 2013/55/EU on Education and Training for Sectoral Practice Such as That of Pharmacy. Available online: http://eur-lex.europa.eu/legal-content/FR/TXT/?uri=celex: 32013L0055 (accessed on 19 September 2018).

3. The European Higher Education Area (EHEA). Bologna Agreement of Harmonisation of European University Degree Courses. Available online: http:/ / www.ehea.info/ (accessed on 19 September 2018).

4. World Health Organisation (WHO). Global Health Observatory Statistics $2016 . \quad$ Available online: http:/ / www.who.int/gho/publications/world_health_statistics/2016/Annex_B/en/ (accessed on 19 September 2018).

5. European Health Information Gateway. Total Health Expenditure as \% of GDP. Available online: https: //gateway.euro.who.int/en/indicators/hfa_566-6711-total-health-expenditure-as-of-gdp/ (accessed on 19 September 2018).

6. Erasmus Programme for Student and Staff Exchange in the EU. Available online: https://info.erasmusplus. $\mathrm{fr} /$ (accessed on 19 September 2018).

7. Atkinson, J. The Country Profiles of the PHARMINE Survey of European Higher Educational Institutions Delivering Pharmacy Education and Training. Pharmacy 2017, 3, 34. [CrossRef] [PubMed] 
8. Slovenian Chamber of Pharmacies. Available online: http://www.lzs.si/Aboutus/tabid/218/language/slSI/Default.aspx (accessed on 19 September 2018).

9. Zakon o Lekarniški Dejavnosti (ZLD-1) (Pharmacy Practice Act), Uradni list RS, št. 85/201. Official Gazette of the Republic of Slovenia. Available online: http:/ / www.pisrs.si/Pis.web/pregledPredpisa?id=ZAKO7375\# (accessed on 20 December 2018).

10. Republic of Slovenia, Ministry of Health. Deliverance of Medicinal Products. Available online: http://www.mz.gov.si/si/pogoste_vsebine_za_javnost/izdaja_zdravil_prek_medmrezja/ (accessed on 19 September 2018).

11. Srednja Šola za Farmacijo, Kozmetiko in Zdravstvo (Secondary School for Pharmacy, Cosmetics and Healthcare). Available online: www.ssfkz.si (accessed on 19 September 2018).

12. System for the Recognition of Professional Qualifications. EU Directive 2005/36/EC. Available online: http:/ / eur-lex.europa.eu/legal-content/EN/TXT/HTML/?uri=LEGISSUM:c11065\&from=FR (accessed on 19 September 2018).

13. EFPIA-The European Federation of Pharmaceutical Industries and Associations: The Pharmaceutical Industry in Figures, Key Data 2017. Available online: https:/ /www.efpia.eu/publications/downloads/ (accessed on 19 September 2018).

14. University of Ljubljana, Faculty of Pharmacy. Available online: http://www.ffa.uni-lj.si (accessed on 20 December 2018).

15. JAZMP - Agency for Medicinal Products and Medical Devices of the Republic of Slovenia. Available online: https:/ / www.jazmp.si/en/ (accessed on 20 December 2018).

16. National Agency for Quality in Higher Education NAKVIS. Available online: http:/ / test.nakvis.si/en-GB/ Content/Details/ 8 (accessed on 20 December 2018).

17. Doctoral study Biomedicine at University of Ljubljana. Available online: https://www.uni-lj.si/study/ doctoral/biomedicine/ (accessed on 20 December 2018).

18. Postgraduate specializations at UL FFA. Available online: http://www.ffa.uni-lj.si/en/study/specializations (accessed on 20 December 2018).

19. EuSpLM: European Register of Specialists in Laboratory Medicine of the the Association for Clinical Biochemistry and Laboratory Medicine. Available online: http:/ /www.acb.org.uk/whatweare/joining/ EC4.aspx (accessed on 19 September 2018).

20. Chamber of Laboratory Medicine of Slovenia. Available online: http://www.zlms.si (accessed on 19 December 2018).

21. Prospectus of the Uniform Master's Pharmacy Programme, University of Ljubljana, Faculty of Pharmacy. Available online: www.ffa.uni-lj.si (accessed on 19 September 2018).

22. Atkinson, J.; De Paepe, K.; Sánchez Pozo, A.; Rekkas, D.; Volmer, D.; Hirvonen, J.; Bozic, B.; Skowron, A.; Mircioiu, C.; Marcincal, A.; et al. Does the Subject Content of the Pharmacy Degree Course Influence the Community Pharmacist's Views on Competencies for Practice? Pharmacy 2015, 3, 137-153. [CrossRef] [PubMed]

23. Central European Exchange Program for University Studies (CEEPUS) Networks and Bilateral Cooperation. Available online: http:/ / www.cmepius.si/en/higher-education/ceepus.aspx (accessed on 19 September 2018).

24. EANM-European association for nuclear medicine. Available online: https://www.eanm.org/ (accessed on 20 December 2018).

25. IMI-The Pharmaceutical Medicine Training Programme. Available online: https://cordis.europa.eu/ project/rcn/203685_en.html (accessed on 19 September 2018).

(C) 2018 by the authors. Licensee MDPI, Basel, Switzerland. This article is an open access article distributed under the terms and conditions of the Creative Commons Attribution (CC BY) license (http:/ / creativecommons.org/licenses/by/4.0/). 